\title{
Amaranthus cruentus L. is suitable for cultivation in Central Italy: field evaluation and response to plant densities
}

\author{
Paolo Casini, Felice La Rocca \\ Department of Agrifood and Environmental Science, University of Florence, Italy
}

\begin{abstract}
The aim of this study was to determine the possibility of amaranth cultivation in Central Italy and to determine the optimum plant density. Field trials were carried out in 2011 and 2012 under non-irrigated conditions in Tuscany $\left(43^{\circ} 18^{\prime} \mathrm{N}, 11^{\circ} 47^{\prime} \mathrm{E}\right)$. Twelve accessions of two amaranth species (Amaranthus cruentus $\mathrm{L}$. and A. hypochondriacus $\mathrm{L}$.) were utilised. Genotypes were evaluated over a two-year period using a RCB design with three replicates. The effects of plant density were investigated in 2012. A with a split-plot design was used, where the $A$. cruentus accessions (AMES 5148, PI 511719 and PI 643045) constituted the main plots. Plant densities $\left(7.5,15,30\right.$ and 60 plants $\left.\mathrm{m}^{-2}\right)$ constituted the subplots. Plants were transplanted at the 3-4 true leaf stage. Morphological traits were determined using 5 plants selected from the two central rows of the sampling area. Plots were hand-harvested and cleaned with a mechanical grid with appropriate sieve diameters. A. cruentus was shown to be more suitable to the Central Italy agro-ecological conditions than $A$. hypochondriacus. The accessions derived from Mexico (PI 477913, PI 576481, PI 643045, PI 643053, and PI 6495079), Guatemala (PI 511719) and Puerto Rico (AMES 5148), had both higher grain yields and a greater stability over the two-year period, with a mean grain production ranging from 2.8 to $3.2 \mathrm{t} \mathrm{ha}^{-1}$. The severe climatic stress in 2012 (high temperatures and aridity), resulted in a $43-60 \%$ reduction in seed production compared to that of the previous year. Under these conditions, PI 511719, AMES 26015, AMES 5386, AMES 5148, PI 477913 yielded on average $1.9 \mathrm{tha}^{-1}$. Yields of $A$. hypochondriacus were negligible in both years, probably attributable to greater photoperiod sensitivity, resulting in reduced
\end{abstract}

Correspondence: Paolo Casini, Department of Agrifood and Environmental Science, P.le delle Cascine 18, 50144 Firenze, Italy.

Tel.: +39.055.2755710 - Fax: +39.055 .332472 .

E-mail: paolo.casini@unifi.it

Key words: Amaranthus cruentus, Amaranthus hypochondriacus, Central Italy, planting density.

Funding: the research was funded by the Ente Cassa di Risparmio di Firenze.

Received for publication: 7 April 2014.

Revision received: 3 October 2014.

Accepted for publication: 3 October 2014.

(C) Copyright P. Casini and F. La Rocca, 2014

Licensee PAGEPress, Italy

Italian Journal of Agronomy 2014; 9:602

doi:10.4081/ija.2014.602

This article is distributed under the terms of the Creative Commons Attribution Noncommercial License (by-nc 3.0) which permits any noncommercial use, distribution, and reproduction in any medium, provided the original author(s) and source are credited. flowering and delayed maturity. By increasing density up to 60 and 30 plants $\mathrm{m}^{-2}$ for PI 511719 and AMES 5148, respectively, grain production was increased by $55 \%$. As the plant population increased, plant height, panicle length and diameter, basal stem diameter and branches per plant were reduced. AMES 5148 plants were composed of one single stem with apical panicles at a density of 30 plants $\mathrm{m}^{-2}$, whilst the other two accessions were similar at the highest plant density. Branch number per plant was negatively correlated with grain production $\left(\mathrm{r}=-0.536^{* *}\right)$. Hence, A. cruentus may be grown in Central Italy even under arid conditions, using a density of either 30 or 60 plants $\mathrm{m}^{-2}$ according to the genotype used.

\section{Introduction}

The rediscovery and valorisation of both indigenous and exotic pseudo-cereals for cultivation in Italy has led to a renewed interest in species that have remained largely neglected worldwide (National Research Council, 1984). Buckwheat (Fagopyrum esculentum Moench.) and quinoa (Chenopodium quinoa Willd.) (Casini and Proietti, 2002) have contributed to the creation of markets in both the food and non-food sectors. An additional species that has recently managed to gain some market popularity is amaranth (Amaranthus spp.), native to Mexico and Central America, which along with corn, beans, various pumpkin species and quinoa constituted one of the principle foods of the Maya and Aztecs (Pola Lopez et al., 2007; Rastogi and Shukla, 2013). The cultivation of these plants was in progressive decline until the early twentieth century, as they were prohibited in the days of conquistadores, who considered their use in the religious ceremonies of the locals offensive to Christian traditions (National Research Council, 1984). For centuries, these species were confined to small communities in Mexico and the Andean Plateau, where, fortunately, some degree of biodiversity was preserved (Saunders and Becker, 1984).

The rediscovery of amaranth as a valuable food resource dated back to the 1970 s when, studies, undertaken by Dowton (1973), demonstrated the remarkable nutritional properties of the most common species: Amaranthus cruentus L., A. hypochondriacus $\mathrm{L}$., A. caudatus $\mathrm{L}$. and $A$. edulis Speg. Research on the first two species resulted in the development of a major market for amaranth in the United States, China, India and the Czech Republic. Amaranth is currently cultivated in the aforementioned countries, and is given similar recognition along with other industrial crops (Tucker, 1986; Granados and Lopez, 1990; Gimplinger et al., 2007).

The main characteristics of this species include the high protein (15-18\%), as well as lysine and calcium contents, with averages of 5.2 and $0.37 \mathrm{~g} / 100 \mathrm{~g}$ dry matter, respectively (Petr et al., 2003). Importantly, the species is distinguishable by the absence of gluten and is, therefore, suitable for people with celiac disease (Ballabio et al., 2011). In particular, the lysine content is higher in amaranth than in certain plant products (such as grains, beans, soya) and animal sources (meat, milk, eggs), thereby ensuring a high market potential. 
Until recently, this plant has been confined almost exclusively to specialised health sectors (Hackman and Mayers, 2003). Amaranth, in addition to constituting the basis of a large number of cooked or baked products, is also used in the preparation of food-bars, snacks, muesli, popped seeds, and other products such as biscuits and bread (Teutonico and Dietrich, 1985).

Equally interesting, is the use of amaranth in the non-food sector, which has not been investigated to the extent as that of the food sector. The cosmetic and pharmaceutical industries benefit primarily due to the high squalene content (4-5\%) of the oil (He et al., 2002; Berganza et al., 2003). This compound is structurally very similar to $\beta$-carotene, an intermediate metabolite in the synthesis of cholesterol. Recent studies (Shin et al., 2004; Gonor et al., 2006) have shown that squalene can be included among the drugs effective at reducing blood cholesterol.

Amaranth oil, contained in the seeds, comprises an average of $6.0 \%$ of the seed mass (He et al., 2003). Of particular interest are the tocopherols (compounds generally referred to as vitamin $E$ ) used in the cosmetic industry especially in the field of skin and hair care, and, more generally, in various formulas for allergy sufferers. The recognised properties are attributable to the high anti-aging antioxidant power (Khandaker et al., 2008).

Although the potential of this pseudo-cereal is well established outside the areas of origin, in Italy amaranth has received limited attention. Only very few papers on amaranth cultivation in Italy for seed production are available. Moreover, all trials were carried out in the South (Alba et al., 1997; Lovelli et al., 2005; Rivelli et al., 2008). In fact, works of Massantini et al. (1987) and Ercoli et al. (1987) (Pisa, Central Italy) were devoted to protein production from fresh leaves. There are no papers that report seed production in Central Italy as well as on the effects of planting densities.

The aim of the research presented in the present work was to analyse twelve amaranth accessions for their potential cultivation in Central Italy. Therefore, seed protein and oil content was examined in each accession. In addition, effects of increasing plant densities were examined in order to determine the optimal planting density for cultivation.

\section{Materials and methods}

\section{Experiment 1: genotype evaluation}

Two field experiments were carried out in 2011 and 2012 in Tuscany, Central Italy at the Centro per il Collaudo ed il Trasferimento dell'Innovazione di Cesa (Arezzo) $\left(43^{\circ} 18^{\prime} \mathrm{N}\right.$; $\left.11^{\circ} 47^{\prime} \mathrm{E}\right)$, on a neutral, loamy-sandy soil. The principle physical and chemical characteristics of the soil were as follows: sand $36.4 \%$; loam $37.7 \%$; clay $25.9 \%$; total N 0.114\%; P (Olsen) 11 ppm; exchangeable calcium, magnesium and potassium: 4250, 620 and $136 \mathrm{ppm}$ respectively; $\mathrm{pH} 7.2$.

A comparative study was carried out on 10 accessions of Amaranthus cruentus and 2 accessions of A. hypochondriacus (Table 1), provided by the North Central Regional Plant Introduction Station (Iowa State University, USA). The experimental design was a complete randomised block with three replicates. Plots were $2.0 \mathrm{~m}$ wide (four rows wide with $0.5 \mathrm{~m}$ row spacing) and $5.0 \mathrm{~m}$ long. The sampling area was comprised of two central rows, each $3 \mathrm{~m}$ long. In order to ensure the success of the trial, a density of 33 plants $\mathrm{m}^{-2}$ was chosen and seeds were sown in seedling trays in the first days of April, after which seedlings were transplanted on 13 May and 22 May 2012.

Fertilisers were applied before transplanting as follows: $46 \mathrm{~kg} \mathrm{ha}^{-1}$ of $\mathrm{N}$ and $100 \mathrm{~kg} \mathrm{ha}^{-1}$ of $\mathrm{P}_{2} \mathrm{O}_{5}$. Plots were hand-weeded twice during plant development. Due to a flea beatle attack (Chaetocnema tibialis Illiger), an insecticide treatment (deltamethrine) was applied 10 days after transplanting. Morphological characteristics (plant height, length and basal diameter of the main panicle, stem diameter) were carried out on a sample of 5 plants, which were selected from the two central rows. Hand-harvesting was carried out at maturity by cutting the plants at soil level over a period of 30 days, starting from the 26 July 2011 and the 19 July 2012, respectively, according to genotype maturation. Climatic data, registered during the field experiments, are shown in Figure 1.

Crude protein and oil content of the seeds were analysed in triplicate. The protein content was calculated by multiplying the nitrogen content by 6.25 . Nitrogen content of $500 \mathrm{mg}$ flour samples was determined by the FlashEA 1112 Series analyser (Thermo Fisher Scientific Inc., Waltham, MA, USA). Oil content was carried out on a $5 \mathrm{~g}$ sample using the Soxhlet extraction procedure with petrolether as solvent.

\section{Experiment 2: plant density}

The experiment was carried out in 2012 according to a RCB splitplot design with three replicates with a plot size of $20.0 \times 2.0 \mathrm{~m}$, which constituted the main factor (accessions AMES 5148, PI 511719 and PI 643045 ). The subplots were $2.0 \mathrm{~m}$ wide (four rows wide with $0.5 \mathrm{~m}$ row spacing) and $5.0 \mathrm{~m}$ long. The main plots were split into four sub-plots containing the densities of $7.5,15.0,30.0$ and 60.0 plants $\mathrm{m}^{-2}$. The sampling area was comprised of two central rows, each $3 \mathrm{~m}$ long. In order to attain the correct planting density within each plot, seedlings at the 3-4 true leaf stage, were transplanted on May 22 in the designated spacing. Fertilisers were distributed before transplanting as follows: $46 \mathrm{~kg} \mathrm{ha}^{-1}$ of $\mathrm{N}$ and $100 \mathrm{~kg} \mathrm{ha}^{-1}$ of $\mathrm{P}_{2} \mathrm{O}_{5}$. Plots were hand-weeded twice during the growth cycle. Moreover, 15 days after transplanting, the seedlings were treated with the insecticide deltamethrine. Morphological traits of the crop were evaluated by considering five sample plants marked in each sample area. During crop development, the visual ground cover of the plants was estimated at 28, 40, 55, 68 and 77 days after transplanting (DAT). Relative increments of ground cover, branch per plant and plant height were calculated as follows:

Table 1. Experiment 1. Accessions and their origins.

\begin{tabular}{lll} 
Accession & Origin & Species \\
AMES 2003 & Ethiopia & A. cruentus \\
AMES 5148 & Puerto Rico & A. cruentus \\
\hline AMES 5386 & India & A. cruentus \\
AMES 26015 & Poland & A. cruentus \\
\hline PI 477913 & Mexico & A. cruentus \\
PI 511719 & Guatemala & A. cruentus \\
\hline PI 576481 & Mexico & A. cruentus \\
PI 643045 & Mexico & A. cruentus \\
\hline PI 643053 & Mexico & A. cruentus \\
PI 649507 & Mexico & A. cruentus \\
\hline AMES 5615 & Taiwan & A. hypochondriacus \\
PI 633596 & Nepal & A. hypochondriacus \\
\hline
\end{tabular}




$$
R I_{i}=\frac{x_{i}}{x_{(i-1)}}
$$

were $R_{i}=$ relative increment at time $i$;

$\mathrm{X}_{i}=$ variable measured at time $i$;

$\mathrm{X}_{(i-I)}=$ variable measured at previous time.

The harvest was performed manually starting from 9 August. Duration of maturation was genotype dependent, and the different plots were harvested accordingly.

\section{Statistical analysis}

Data collected in experiment 1 were processed utilising a mixed model of analysis of variance (ANOVA), where accession was considered as a fixed effect factor, and year as random effect factor. The expected components of the variance, and the ANOVA model are both reported in Table 2. For Experiment 2, data were processed utilising a fixed model of ANOVA, where both factors of variability (plant density and accessions) were considered as fixed effect factors. The expected components of the variance and the ANOVA model are reported in Table 3. To verify the difference between the means, the multiple comparison Tukey's test was performed.

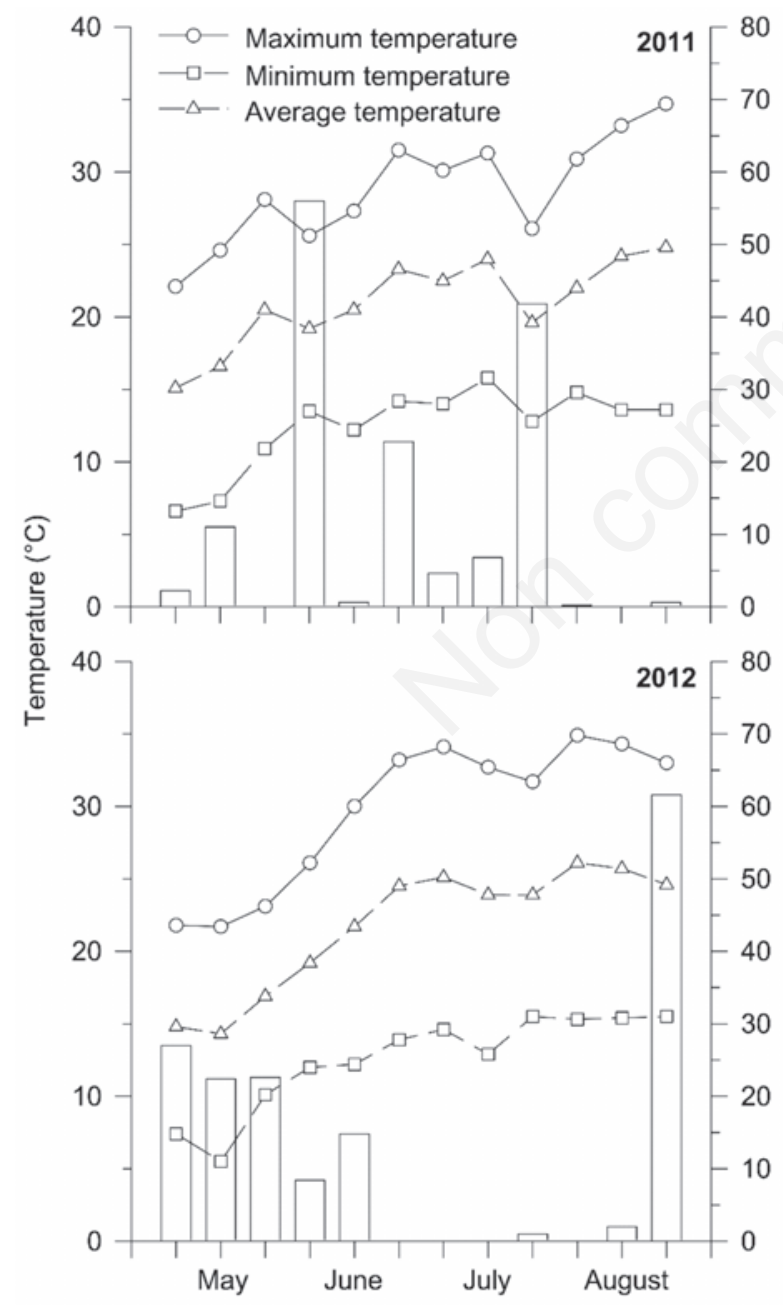

Figure 1. Ten-day temperature and rainfall recorded during the field plot experiments.

\section{Results}

\section{Experiment 1: genotypes evaluation}

The seasonal trend was characterised by particularly warm and dry conditions, thereby placing strain on the hardiness and drought tolerance of this plant. The total rainfall recorded during the trials (Figure 1) was 147 and $160 \mathrm{~mm}$, in 2011 and 2012, respectively. However, from the second week of June until the end of August in 2012, the observed maximum temperatures were almost always above $30.0^{\circ} \mathrm{C}$ (maximum $34.9^{\circ} \mathrm{C}$ ). In addition to high temperatures, the period was also characterised by drought with only $5 \mathrm{~mm}$ of rain being measured up to the second week of August. Therefore, immediately after the development of the panicle (the budstage phase) and throughout subsequent development and flowering, plants had to cope with water stress that was not relieved by irrigation. The ANOVA analysis reported in Table 4 showed how the effect of both year and genotype had a significant impact on almost all the parameters measured, with the exception of panicle length and diameter, as well as stem diameter. The interaction Accession $\times$ Year was significant at $\mathrm{P} \leq 0.01$ for seed yield, several biometric characters and time of harvest.

The averages reported in Table 5 show that, for all accessions, the

Table 2. Experiment 1. Expected components of the variance and the analysis of variance model.

\begin{tabular}{|c|c|c|}
\hline Source of variation & df & $\begin{array}{l}\text { Expected components } \\
\text { of the variance }\end{array}$ \\
\hline Year $(Y)$ & 1 & $\sigma_{\mathrm{e}}^{2}+3 \cdot 12 \cdot \sigma_{\mathrm{r}}^{2}$ \\
\hline Accession (A) & 11 & $\sigma_{e}^{2}+3 \cdot \gamma_{\mathrm{int} Y \times A}^{2}+3 \cdot 2 \cdot \frac{j_{j}}{12-1}$ \\
\hline Interaction $\mathrm{Y} \times \mathrm{A}$ & 11 & $\sigma_{\mathrm{e}}^{2}+3 \cdot \gamma_{\text {int } Y x A}^{2}$ \\
\hline Error & 48 & $\sigma_{\mathrm{e}}^{2}$ \\
\hline Total & 71 & \\
\hline
\end{tabular}

Table 3. Experiment 2. Expected components of the variance and the analysis of variance model.

$\begin{array}{lcl}\begin{array}{l}\text { Source of variation } \\ \text { If }\end{array} & \begin{array}{l}\text { Expected components } \\ \text { of the variance }\end{array} \\ \text { Plant density (PD) } & 3 & \sigma_{e}^{2}+3 \cdot 3 \cdot \frac{\sum_{i=1}^{4} \alpha_{i}^{2}}{4-1} \\ \text { Accession (A) } & 2 & \sigma_{e}^{2}+3 \cdot 4 \cdot \frac{\sum_{j=1}^{3} \beta_{j}^{2}}{3-1} \\ & \\ \text { Plant density (PD) } & 3 & \sigma_{e}^{2}+3 \cdot \frac{\sum_{i=1}^{4} \sum_{j=1}^{3} \gamma_{i j}^{2}}{(4-1) \cdot(3-1)} \\ \text { Error } & 24 & \sigma_{\mathrm{e}}^{2} \\ \text { Total } & 35 & \end{array}$

df, degree of freedom. 
development of the panicle began in a period between 20 and 29 DAT and that, only in the genotypes of $A$. cruentus, maturation was achieved within 77 DAT. Ripening was significantly delayed by an average of 30 days in the two A. hypochondriacus genotypes (AMES 5615 and PI 633596). As part of the morphological characteristics, the length of the main panicle was predominantly affected by the prolonged drought in the second year of experimentation. The values were shown to decrease by $60 \%$, from 43.2 to $17.4 \mathrm{~cm}$. A . hypochondriacus was characterised by more developed panicles, even if no significant differences were observed between the two accessions. The panicle branches varied significantly among accessions and this trait was also sensitive to the different climatic conditions between the two years. Similar to panicle length, branch number was significantly reduced by $65 \%$ in the 2012 season in comparison to the previous year. Average seed production was very variable according to both genotype and year, with maximum yields clearly detectable across all species of Mexican origins, with AMES 5148 (Puerto Rico) and PI 511719 (Guatemala), yielding 3.2 and $2.8 \mathrm{t} \mathrm{ha}^{-1}$, respectively. Significantly lower production yields were observed in both genotypes of $A$. hypochondriacus $\left(0.5-0.1 \mathrm{t} \mathrm{ha}^{-1}\right)$. Significant genotype variation was evident for both protein and total oil content in the seeds. Values greater than $16 \%$ for the protein content were recorded for AMES 2003, AMES 5386, AMES 26015, PI 649507 ( $A$. cruentus), as well as for IP 633596 (A. hypochondriacus). With regard to oil content, values greater than $5 \%$ were reported for the Mexican genotypes PI 477913, PI 649507 and PI 643053.

Figure 2 shows the significant interactions Years $\times$ Accessions as sources of variability. Worthy of attention was the negative impact of the 2012 season on all parameters considered, and the different trends observed for the A. hypochondriacus accessions, especially with regard to the time of harvest and grain yield. Regarding the former, the two genotypes of this species reached maturity in a period exceeding 110 DAT in comparison to the average 70 DAT of the $A$. cruentus accessions. Some genotypes of the latter species showed a more rapid maturity up to 20 DAT in 2012 compared to 2011 , a phenomenon easily attributable to the aforementioned climatic conditions. Similarly, stem diameter, plant height and seed yield were significantly reduced. In particular, for yield production, three groups could be distinguished. Group $A$ with an average yield reduction of $60 \%$ in 2012 , compared to 2011, a $B$ group composed exclusively of $A$. cruentus genotypes of Mexican origin (PI 576481, PI 643053, PI 549507) with an average yield reduction of $43 \%$

Table 4. Experiment 1. Analysis of variance.

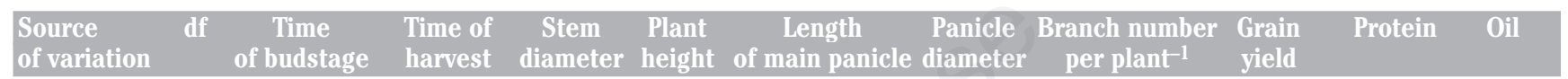

\begin{tabular}{|c|c|c|c|c|c|c|c|c|c|c|c|}
\hline Year (Y) & 1 & $45.125^{\mathrm{ns}}$ & $5338.889 * *$ & $48.758^{* *}$ & $58,072.320 * *$ & $12,115.277^{* *}$ & $0.374^{\mathrm{ns}}$ & $281.636^{* *}$ & $69.090^{* *}$ & $2.071 *$ & $0.031^{\mathrm{ns}}$ \\
\hline Accession (A) & 11 & 479.819* & $15,121.111^{* *}$ & $6.764^{\mathrm{ns}}$ & $5014.947^{\mathrm{ns}}$ & $1550.244^{\mathrm{ns}}$ & $2.773^{\text {ns }}$ & $81.647^{* *}$ & $84.235^{* *}$ & $35.406^{* *}$ & $12.770^{* *}$ \\
\hline $\mathrm{Y} \times \mathrm{A}$ & 11 & $275.708^{\text {ns }}$ & $1136.444^{* *}$ & $5.968^{* *}$ & $5199.367^{* *}$ & $583.256^{\text {ns }}$ & $6.703^{* *}$ & $18.124^{\text {ns }}$ & $15.119 * *$ & $5.548^{\mathrm{ns}}$ & $2.078^{\text {ns }}$ \\
\hline Error & 48 & 664.000 & 453.333 & 8.609 & 8400.747 & 2327.551 & 4.133 & 64.708 & 8.682 & 15.531 & 10.658 \\
\hline
\end{tabular}

$\mathrm{df}$, degree of freedom; ns, not significant. ** Significant at $\mathrm{P} \leq 0.01$; * significant at $\mathrm{P} \leq 0.05$.

Table 5. Experiment 1. Means of morphological characteristics of the accessions, grain yield, protein and seed oil content.

\begin{tabular}{|c|c|c|c|c|c|c|c|c|c|c|}
\hline $\begin{array}{l}\text { Source } \\
\text { of variation }\end{array}$ & $\begin{array}{c}\text { Time } \\
\text { of budstage } \\
\text { (DAT) }\end{array}$ & $\begin{array}{c}\text { Time } \\
\text { of harvest } \\
\text { (DAT) }\end{array}$ & $\begin{array}{c}\text { Stem } \\
\text { diameter } \\
(\mathrm{cm})\end{array}$ & $\begin{array}{l}\text { Plant } \\
\text { height } \\
(\mathrm{cm})\end{array}$ & $\begin{array}{l}\text { Length of } \\
\text { main panicle } \\
(\mathrm{cm})\end{array}$ & $\begin{array}{l}\text { Panicle } \\
\text { diameter } \\
\text { (cm) }\end{array}$ & $\begin{array}{l}\text { Branch number } \\
\text { per plant }^{-1}\end{array}$ & $\begin{array}{l}\text { Grain yield } \\
\mathrm{ha}^{-1}\end{array}$ & $\begin{array}{l}\text { Protein } \\
\text { (\%) }\end{array}$ & $\begin{array}{l}\text { Oil } \\
(\%)\end{array}$ \\
\hline \multicolumn{11}{|c|}{ Mean over accessions } \\
\hline AMES 2003 & $22.0^{\mathrm{ac}}$ & $70.2^{\mathrm{bc}}$ & $1.5^{\mathrm{bc}}$ & $106.2^{c}$ & $20.9^{b}$ & $1.9^{\mathrm{cd}}$ & $5.8^{\mathrm{ab}}$ & $1.9^{b}$ & $16.4^{\mathrm{a}}$ & $4.0^{\mathrm{cd}}$ \\
\hline AMES 5148 & $26.2^{\mathrm{ac}}$ & $77.5^{\mathrm{c}}$ & $2.2^{\mathrm{ac}}$ & $127.7^{\mathrm{ab}}$ & $34.5^{\mathrm{ab}}$ & $2.3^{\mathrm{ab}}$ & $4.0^{\mathrm{ad}}$ & $3.2^{\mathrm{a}}$ & $15.2^{\mathrm{bd}}$ & $4.7^{\mathrm{ad}}$ \\
\hline AMES 5386 & $24.7^{\mathrm{ac}}$ & $67.3^{c}$ & $1.7^{\mathrm{bc}}$ & $121.0^{\mathrm{ac}}$ & $27.6^{\mathrm{ab}}$ & $1.9^{\mathrm{bd}}$ & $4.8^{\mathrm{ac}}$ & $1.5^{b}$ & $16.0^{\mathrm{ab}}$ & $4.3^{\mathrm{bd}}$ \\
\hline AMES 26015 & $24.8^{\mathrm{ac}}$ & $74.3^{\mathrm{bc}}$ & $1.5^{\mathrm{c}}$ & $116.4^{\mathrm{cb}}$ & $29.2^{\mathrm{ab}}$ & $1.8^{\mathrm{d}}$ & $6.1^{\mathrm{a}}$ & $1.2^{\mathrm{bc}}$ & $16.2^{\mathrm{ab}}$ & $3.8^{\mathrm{d}}$ \\
\hline PI 477913 & $28.8^{\mathrm{ab}}$ & 73. $0^{\text {ac }}$ & $2.3^{\mathrm{ab}}$ & $119.4^{c b}$ & $30.9^{a b}$ & $2.2^{\mathrm{ac}}$ & $3.1^{\mathrm{cd}}$ & $3.2^{\mathrm{a}}$ & $16.9^{\mathrm{a}}$ & $5.0^{\mathrm{ab}}$ \\
\hline PI 511719 & $20.7^{c}$ & $74.8^{\mathrm{bc}}$ & $1.8^{\mathrm{ac}}$ & $121.8^{\mathrm{ac}}$ & $30.6^{\mathrm{ab}}$ & $1.9^{\mathrm{bd}}$ & $3.4^{\text {cd }}$ & $2.8^{\mathrm{a}}$ & $15.7^{a c}$ & $4.5^{\mathrm{ad}}$ \\
\hline PI 576481 & $27.2^{\mathrm{ac}}$ & $72.8^{\mathrm{ac}}$ & $1.8^{\mathrm{ac}}$ & $120.9^{c b}$ & $28.6^{\mathrm{ab}}$ & $2.2^{\mathrm{ac}}$ & $3.5^{\mathrm{cd}}$ & $2.9^{\mathrm{a}}$ & $15.9^{\mathrm{ab}}$ & $4.9^{\mathrm{ac}}$ \\
\hline PI 643045 & $26.2^{\mathrm{ac}}$ & $73.5^{\mathrm{bc}}$ & $2.0^{\mathrm{ac}}$ & $109.7^{\mathrm{cb}}$ & $26 .^{\mathrm{ab}}$ & $2.1^{\mathrm{ad}}$ & $4.6^{\mathrm{ac}}$ & $3.5^{\mathrm{a}}$ & $14.6^{\mathrm{cd}}$ & $5.2^{\mathrm{a}}$ \\
\hline PI 643053 & $25.2^{\mathrm{ac}}$ & $76.5^{c}$ & $2.1^{\mathrm{ac}}$ & $114.6^{\mathrm{cb}}$ & $31.3^{\mathrm{ab}}$ & $2.1^{\text {ad }}$ & $4.1^{\text {ad }}$ & $2.8^{\mathrm{a}}$ & $15.4^{\text {ad }}$ & $5.0^{\mathrm{ab}}$ \\
\hline PI 649507 & $25.0^{\mathrm{ac}}$ & $77.2^{c}$ & $2.0^{\mathrm{ac}}$ & $126.5^{\mathrm{ab}}$ & $28.8^{\mathrm{ab}}$ & $2.3^{\mathrm{a}}$ & $3.6^{\mathrm{bd}}$ & $2.8^{\mathrm{a}}$ & $16.3^{\mathrm{ab}}$ & $4.8^{\mathrm{ac}}$ \\
\hline AMES 5615 & $21.2^{\mathrm{bc}}$ & $108.7^{\mathrm{b}}$ & $2.5^{\mathrm{a}}$ & $139.8^{\mathrm{a}}$ & $35.6^{\mathrm{a}}$ & $2.2^{\mathrm{ac}}$ & $3.8^{\mathrm{ad}}$ & $0.5^{\mathrm{cd}}$ & $14.5^{\mathrm{d}}$ & $4.6^{\mathrm{ad}}$ \\
\hline PI 633596 & $29.3^{\mathrm{a}}$ & $114.8^{\mathrm{a}}$ & $2.1^{\mathrm{ac}}$ & $115.6^{\mathrm{cb}}$ & $39.8^{\mathrm{a}}$ & $1.9^{\mathrm{ad}}$ & $2.2^{d}$ & $0.1^{\mathrm{d}}$ & $16 .^{\mathrm{ab}}$ & $4.9^{\mathrm{ac}}$ \\
\hline$R^{2}$ & 0.33 & 0.70 & 0.09 & 0.07 & 0.09 & 0.20 & 0.18 & 0.48 & 0.61 & 0.50 \\
\hline \multicolumn{11}{|c|}{ Mean over year } \\
\hline 2011 & 24.4 & 88.7 & 2.8 & 148.4 & 43.2 & 2.1 & 6.1 & 3.2 & 15.6 & 4.7 \\
\hline 2012 & 26.0 & 71.5 & 1.1 & 91.6 & 17.4 & 2.0 & 2.1 & 1.2 & 16.0 & 4.6 \\
\hline$R^{2}$ & 0.03 & 0.24 & 0.70 & 0.76 & 0.73 & 0.03 & 0.63 & 0.39 & 0.04 & 0.09 \\
\hline
\end{tabular}

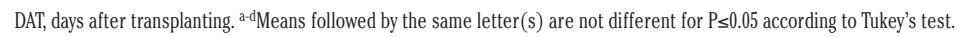


and, finally, a group $C$ composed of the two accessions of $A$. hypochondriacus with low and practically negligible yields both in 2011 and 2012.

The results are the first to be obtained for these accessions in Central Italy over two growing season and confirm previous field trials conducted in the South of Italy (Alba et al., 1997; Rivelli et al., 2008). Moreover, it was shown that $A$. cruentus demonstrated the best adaptability to Tuscan environments in comparison to A. hypochondriacus in terms related to the period of major growth phases such as those of budstage and ripening. Rapid maturity and improved grain yield better characterise $A$. cruentus, although production was significantly influenced by the agro-environmental conditions. A hypochondriacus was photoperiod sensitive. This was evident from both poor flowering and fruit development, as well as from the significant lengthening of the vegetative phase. This feature was even more apparent in the second year of the trial, during which the accessions were subjected to a strong climatic stress, resulting in a significant reduction in the diameter of the main panicle with inevitable negative effects on seed yield.

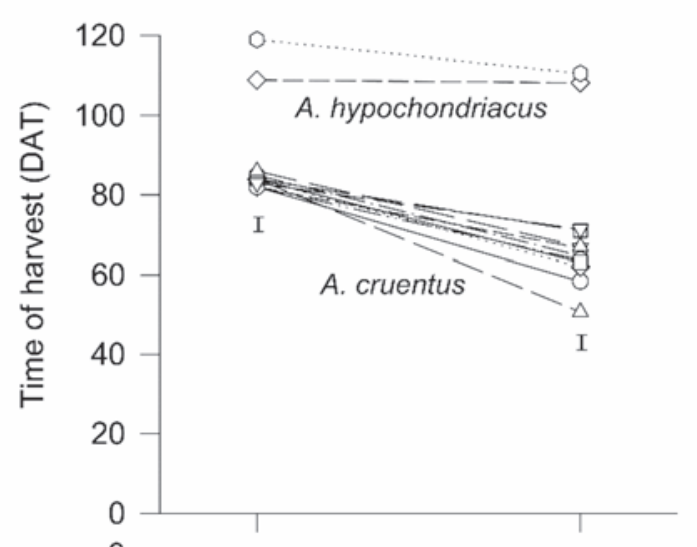

$$
\begin{aligned}
& -\square \text { AMES } 2003 \\
& \square-\text { AMES } 5148 \\
& -\square-\text { AMES } 5386 \\
& -\nabla-\text { AMES } 26015 \\
& \cdots \diamond \cdots \text { PI } 477913 \\
& -0-\text { PI } 511719 \\
& -0-\text { PI } 576481 \\
& -\square-\text { PI } 643045 \\
& -\triangle-\text { PI } 643053 \\
& -\nabla-\text { PI } 649507 \\
& -\diamond-\text { AMES } 5615 \\
& \cdots \circ \cdots \text { PI } 63596
\end{aligned}
$$
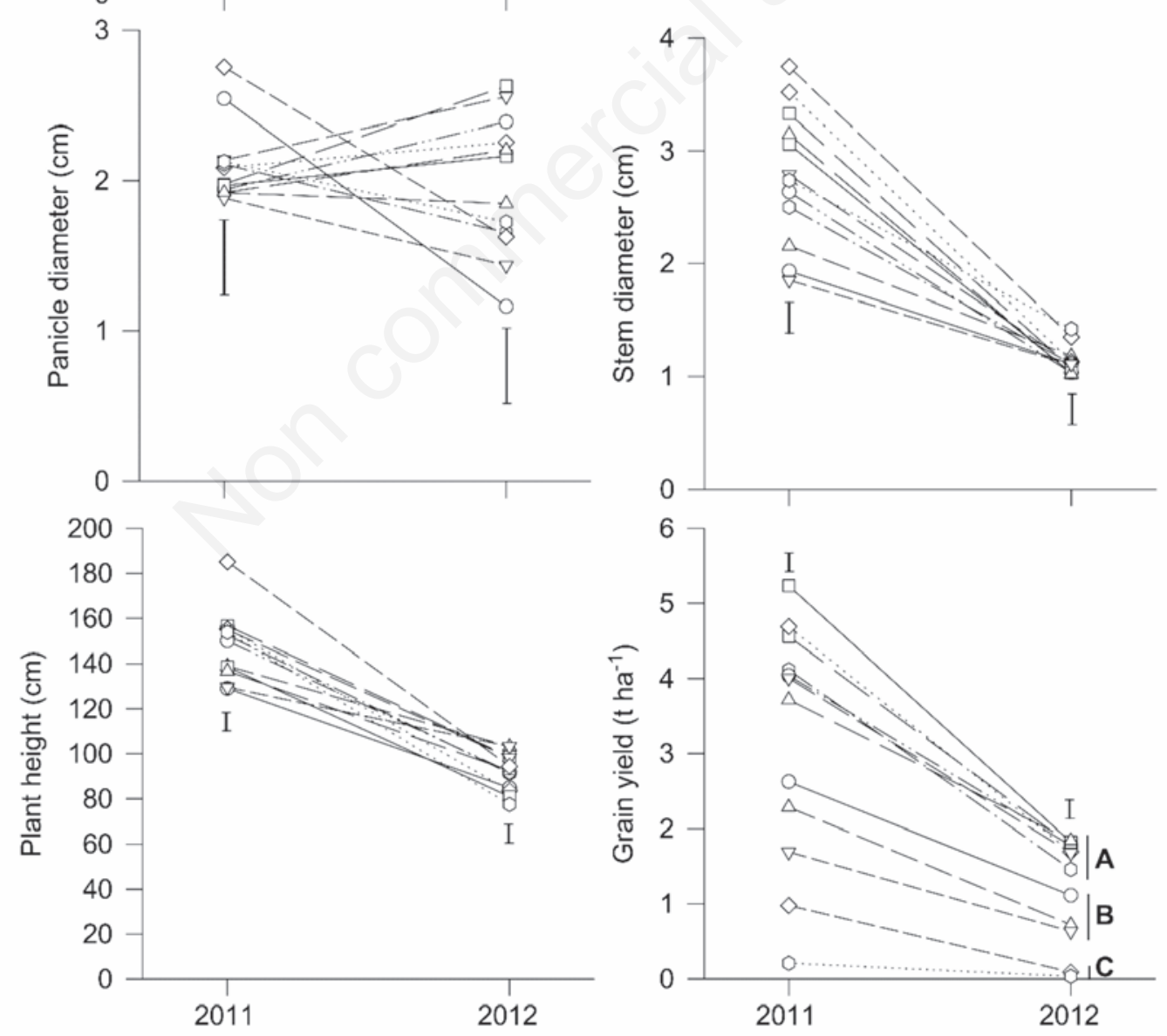

Figure 2. Experiment 1. Mean effect of the year on some morphological traits and on grain yield. 


\section{Experiment 2: plant density}

The ANOVA results for various characteristics are shown in Table 6 . The first observation was related to the non-significance of the interaction Plant density $\times$ Accession $(\mathrm{PD} \times \mathrm{A})$ for all parameters. In contrast, plant density significantly affected most of the characters. Levels of significance at $\mathrm{P} \leq 0.01$ were observed for the following traits: time of harvest, relative increase in ground cover, branch number per plant and plant height as well as other morphological characteristics and seed yield.

The most significant parameters were represented in Figure 3. Ground cover increased with the increase in plant density from 7.5 to 30 plants $\mathrm{m}^{-2}$, but with a concomitant decrease in ramification. Although statistically significant, the effect of density on the maturation period showed small variations around the average 75 DAT. Conversely, the increase in density lead to a significant decrease of the emission of branches per plant. At the lowest density, amaranth plants were characterised by 5 side branches that tended to decrease to an average of 2 at a density of 15 plants $\mathrm{m}^{-2}$. At the highest density, no ramification occurred and there was a single main stem with apical panicles. Parallel to the reduction of side branches, there was a reduction in the length of the main panicle, which decreased from $22 \mathrm{~cm}$ to $13 \mathrm{~cm}$ at a density of 60 plants $\mathrm{m}^{-2}$. A significant positive correlation between panicle length and ramification was evident, $r=0.385^{*}$. This, in turn, also led to a $23 \%$ reduction in the diameter of the main panicle which was significantly correlated to ramification, $\mathrm{r}=0.764^{* *}$.

Amaranth is considered a species showing elasticity in morphology according to the different agro-environmental conditions (Häuptli, 1977; Henderson et al., 2000). This study confirmed such elasticity showing that increased density decreased ramification, which is accompanied by a reduction in the stem diameter, plant height and panicle size. Higher plant densities were related to a higher concentration of panicles on the apex of the single stem of each plant. As a consequence, flowering and ripening of the panicles occurred at the same time, and was not graduated over time as occurs with ramification. Hence, there was less risk of seed dispersal or humidity differences at harvest. Additionally, the reduction in stem diameter has positive effects on both manual and mechanical harvesting, facilitating the cutting of plants (Henderson et al., 2000). Increased plant density per unit area resulted in an increase in seed yield from $1.0 \mathrm{tha}^{-1}$ at a density of
7.5 plants $\mathrm{m}^{-2}$ to $1.30 \mathrm{tha}^{-1}$ at the highest densities.

Literature on the effect of density on seed yield has revealed contrasting results (Gimplinger et al., 2007). Some authors have reported an increase in production with increasing plant density (Guille-Portal et al., 1999; Apaza-Gutierrez et al., 2002; Garcia-Pereyra et al., 2009), whilst others have reported the opposite effect (Weber et al., 1989; Peiretti and Gesumaria, 1998; Yarnia et al., 2010). These discrepancies can be attributed, not only to differences between the species of Amaranthus that were taken into consideration, but also the cultivation environment (Haas and Kauffman, 1984; Putnam, 1990). In addition, as suggested by Apaza-Gutierrez (2002), the effect on yield with increasing density may partly be attributable to different distances in row spacing, besides either the use or absence of double rows, which affords a better utilisation of available space. In that study, yield reduction was mainly attributed to the simultaneous increase of the number of inflorescences per plant at the highest densities that, in turn, lead to a reduction in the number of seeds per plant as the consequence of the highest plant competition. These results, however, were obtained with hybrid between A. hypochondriacus $x$ A. hybridus (Yarnia et al., 2010).

Studies on results in seed yield corroborate findings of the present research in terms of the reduction of the stem diameter (Gimplinger $e t$ al., 2007) and seed production per plant (Apaza-Gutierrez et al., 2002). Similar to that found in the present study (Pearson correlation $\mathrm{r}=$ $\left.-0.618^{* *}\right)$, the latter authors reported a negative correlation between density and diameter of the stem. Increased plant density resulted in increased intraspecific competition, manifested by decreased plant height and length and diameter of the main panicle. In the present study, the increase in yield observed with increased density, can be attributed at least in part to an increase of other yield components such as the number of panicles. Yarnia et al. (2010) reported that as plant density increased, there was a reduction in the oil content of the seeds due to a reduction in fatty acid metabolic activity. In contrast, the present results indicated an increase in oil content from $4.9 \%$ to $5.9 \%$.

The success of a crop, sown in spring-summer, largely depends on a rapid growth during the vegetative phase, thereby increasing ground cover, which helps to reduce weed development. Figure 4 highlighted the trend of ground cover in relation to density and accession. It was shown that different densities leading to increased cover are very different in the first 28 DAT. The best mean increase of $37 \%$ for all accessions, was observed with the lowest density. This was reduced to $10 \%$

Table 6. Experiment 2. Analysis of variance.

\begin{tabular}{|c|c|c|c|c|c|c|c|c|c|c|}
\hline $\begin{array}{l}\text { Source of } \\
\text { variation }\end{array}$ & df & $\begin{array}{l}\text { Time of } \\
\text { budstage }\end{array}$ & $\begin{array}{l}\text { Time of } \\
\text { main } \\
\text { panicle }\end{array}$ & $\begin{array}{l}\text { Time of } \\
\text { harvest }\end{array}$ & $\begin{array}{c}\text { Ground cover } \\
\text { at } 77 \\
\text { DAT }\end{array}$ & $\begin{array}{l}\text { Ground cover } \\
\text { increment }\end{array}$ & $\begin{array}{c}\text { Stem } \\
\text { diameter } \\
\text { at } 77 \mathrm{DAT}\end{array}$ & $\begin{array}{c}\text { Stem } \\
\text { diameter } \\
\text { increment }\end{array}$ & $\begin{array}{c}\text { Stem } \\
\text { per plant } \\
\text { at } 77 \mathrm{DAT}\end{array}$ & $\begin{array}{l}\text { Branch per } \\
\text { plant } \\
\text { increment }\end{array}$ \\
\hline $\begin{array}{l}\text { Plant density } \\
\text { (PD) }\end{array}$ & 3 & $10.111^{\mathrm{ns}}$ & $0.528^{\mathrm{ns}}$ & $40.083^{* *}$ & $135,417.000^{\text {ns }}$ & $0.883^{* *}$ & $3553.000 * *$ & $0.002 \mathrm{~ns}$ & $106,876.000^{* *}$ & $1078.000 * *$ \\
\hline Accession (A) & 2 & $57.556^{* *}$ & $0.056^{\text {ns }}$ & $58.389^{* *}$ & $1,688,889.000$ ** & $0.020^{\mathrm{ns}}$ & $0.036^{\text {ns }}$ & $0.015^{* *}$ & $18,999.000 * *$ & $0.243^{\mathrm{ns}}$ \\
\hline $\mathrm{PD} \times \mathrm{A}$ & 6 & $12.222^{\mathrm{ns}}$ & $2.389^{n s}$ & $5.167^{\mathrm{ns}}$ & $333,33.000^{\text {ns }}$ & $0.017^{\mathrm{ns}}$ & $0.041^{\text {ns }}$ & $0.006^{\mathrm{ns}}$ & $4609.000^{\mathrm{ns}}$ & $0.106^{\mathrm{ns}}$ \\
\hline Error & 24 & 0.000 & 15.333 & 14.000 & $1,766,667.000$ & 0.155 & 0.171 & 0.020 & $19,641.000$ & 0.921 \\
\hline $\begin{array}{l}\text { Source of } \\
\text { variation }\end{array}$ & df & $\begin{array}{c}\text { Plant } \\
\text { height } \\
\text { at } 77 \mathrm{DAT}\end{array}$ & $\begin{array}{c}\text { Plant } \\
\text { height } \\
\text { increment }\end{array}$ & $\begin{array}{l}\text { Length of } \\
\text { main } \\
\text { panicle }\end{array}$ & $\begin{array}{c}\text { Panicle } \\
\text { diameter } \\
\text { at harvest }\end{array}$ & $\begin{array}{l}\text { Whole plant } \\
\text { dry matter }\end{array}$ & Grain yield & Protein & 0il & \\
\hline $\begin{array}{l}\text { Plant density } \\
\text { (PD) }\end{array}$ & 3 & $962,067.000 * *$ & $0.008^{* *}$ & $334,751.000^{* *}$ & $2476.000 * *$ & $57,298.000^{\mathrm{ns}}$ & $1468.000 * *$ & $17.936^{\mathrm{ns}}$ & $6452.000 *$ & \\
\hline Accession (A) & 2 & $1,012,349.000^{* *}$ & $0.001^{\text {ns }}$ & $392,426.000^{* *}$ & $3320.000 * *$ & $70,645.000^{\text {ns }}$ & $0.696^{\mathrm{ns}}$ & $21.650^{*}$ & $1883.000^{\mathrm{ns}}$ & \\
\hline $\mathrm{PD} \times \mathrm{A}$ & 6 & $229,527.000^{\mathrm{ns}}$ & $0.002^{\mathrm{ns}}$ & $46,441.000^{\text {ns }}$ & $0.585^{\mathrm{ns}}$ & $38,048.000^{\text {ns }}$ & $0.09 g^{n s}$ & $9.965^{\mathrm{ns}}$ & $12,059.000^{\mathrm{ns}}$ & \\
\hline Error & 24 & $632,667.000$ & 0.006 & $150,842.000$ & 2413.000 & $758,945.000$ & 1147.000 & 70.757 & $11,982.000$ & \\
\hline
\end{tabular}

$\mathrm{df}$, degree of freedom; DAT, days after transplanting; ns, not significant. **Significant al $P \leq 0.01$; *significant at $\mathrm{P} \leq 0.05$. 
at a density of 15 plants $\mathrm{m}^{-2}$. The increase in initial coverage is positively and significantly correlated with the coverage at 40 DAT $\left(\mathrm{r}=0.660^{* *}\right)$. From Figure 4, the accessions AMES 5148 and PI 643035 showed mean coverage that was equal to $70 \%, 60 \%$ and $70 \%$ at a density of 7.5, 30 and 60 plants $\mathrm{m}^{-2}$, respectively.

Figure 4 shows useful information on the behaviour of the accessions, especially in relation to their tolerance to drought. The graphs in the figure show how, during the protracted dry period until the end of July, three accessions reacted with a partial loss of leaves or with a vegetative stasis, which was then resumed with the slight rains in late July. This type of response was readily noticeable at the lowest density. However, all other densities clearly show the differences that are genotype dependent. PI 511719 showed a constant increase in ground cover up to 77 DAT. In contrast, the other two genotypes reduced coverage by approximately 5-8\%, coinciding with the dry period and high temperatures. Hence, PI 511719 was characterised by a better tolerance to aridity that, unlike the other accessions, resulted in a slight yield increase of $16 \%$, over the dry period and with increasing plant density, from 30 to 60 plants $\mathrm{m}^{-2}$.

The results of the Pearson's correlations (Figure 5) showed interesting trends. Seed yield was shown to be negatively and significantly correlated with the number of branches per plant both at harvest $(r=$ $\left.-0.530^{* *}\right)$, as well as during the vegetative growth of plants. This finding is also confirmed by the negative correlation found between the number of ramifications at harvest, and the dry matter content of the whole plant $\left(\mathrm{r}=-0.536^{* *}\right)$. An inverse relationship between ramification and protein and oil in the seeds was also evident with $r$ values, respectively, equal to $-0.453^{* *}$ and $-0.474^{* *}$.
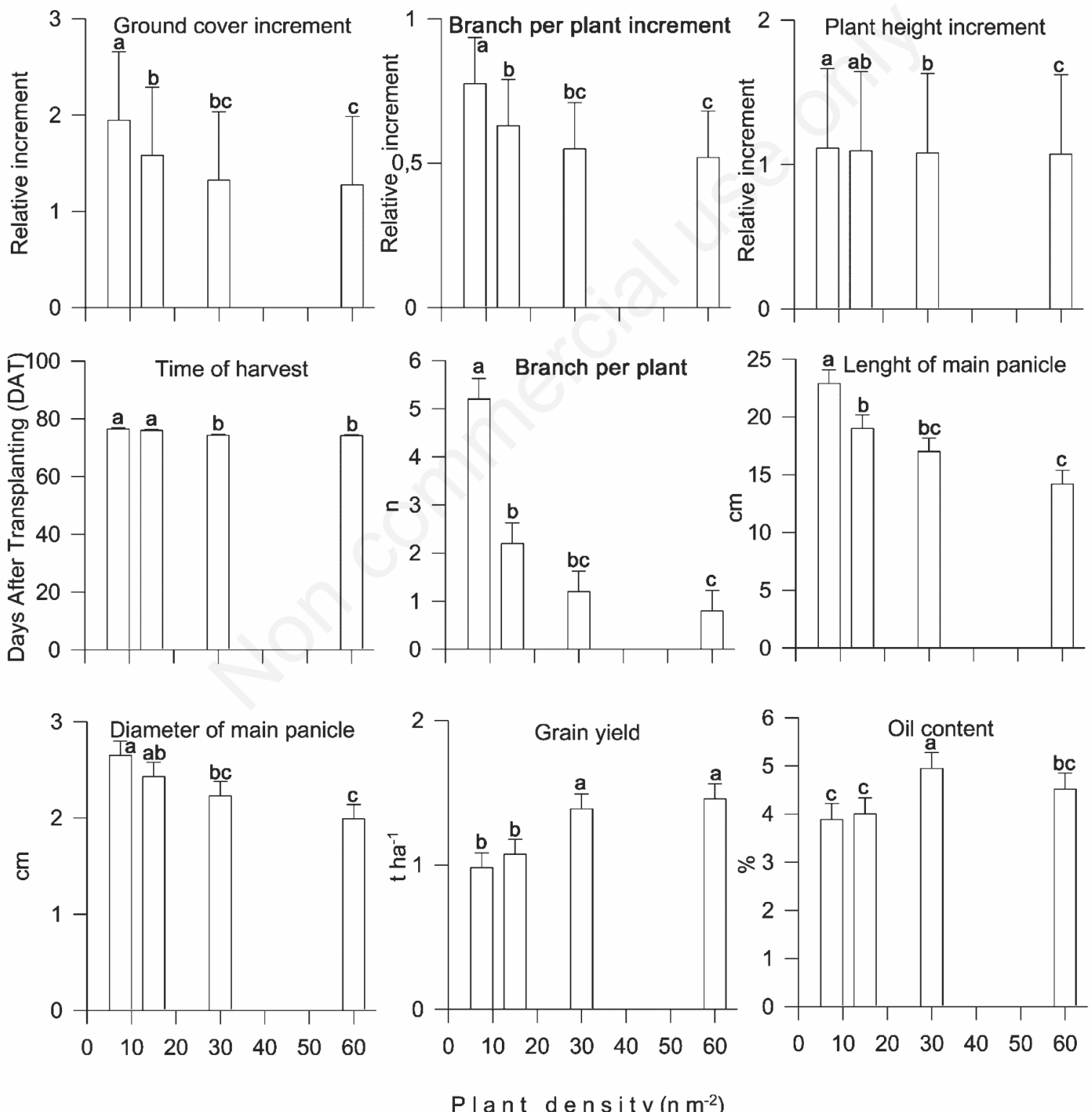

Figure 3. Experiment 2. Mean effects of plant density on some relative increments, morphological traits, grain yield and oil content of seeds. Means followed by the same letter(s) are not different for $\mathbf{P} \leq \mathbf{0 . 0 5}$ according to Tukey's test. 


\section{Discussion and conclusions}

A. cruentus may be cultivated in Central Italy with satisfactory seed yields, and with a very short cycle in arid spring-summer period conditions. The genotypes of Mexican origin, in addition to those of Guatemala and Puerto Rico, are the most productive and/or demonstrate a better yield stability between years $\left(2.8-3.2 \mathrm{t} \mathrm{ha}^{-1}\right)$. A. hypochondriacus, most likely for reasons attributable to photoperiod, was poorly adapted to Tuscany, displaying an extended growth cycle, and with negligible yields, especially in conditions of marked aridity and high average temperatures. Field trials also permitted us to determine the optimal plant density per unit area. The results have clearly shown that densities of 30 and 60 plants $\mathrm{m}^{-2}$ resulted in the best yields for all considered genotypes. The phenotypic plasticity of this species permitted the plants grown at the higher densities to drastically reduce ramification, evident at lower plant densities. As a consequence, the panicles were developed on the apices of the single main stem, which in turn resulted in both a spatial concentration of seed production and a lower degree of scaling with maturation. Such behaviour, together with the reduced stem diameter, and in the case of AMES 5148, the 20 $\mathrm{cm}$ reduction in plant height, could facilitate improved mechanical harvesting. Given that panicles on the main stem matured uniformly, this is an additional important aspect in terms of reducing seed loss through natural dispersal. In fact, removal of the stem would be easier and less traumatic for the plant, and seed maturation would occur with a lower degree of staggered ripening and differences in seed humidity. Of note is that particular attention should be given to the mechanisms adopted by the harvesting machines, taking into consideration the small size of the seed, which is at high risk of damage.
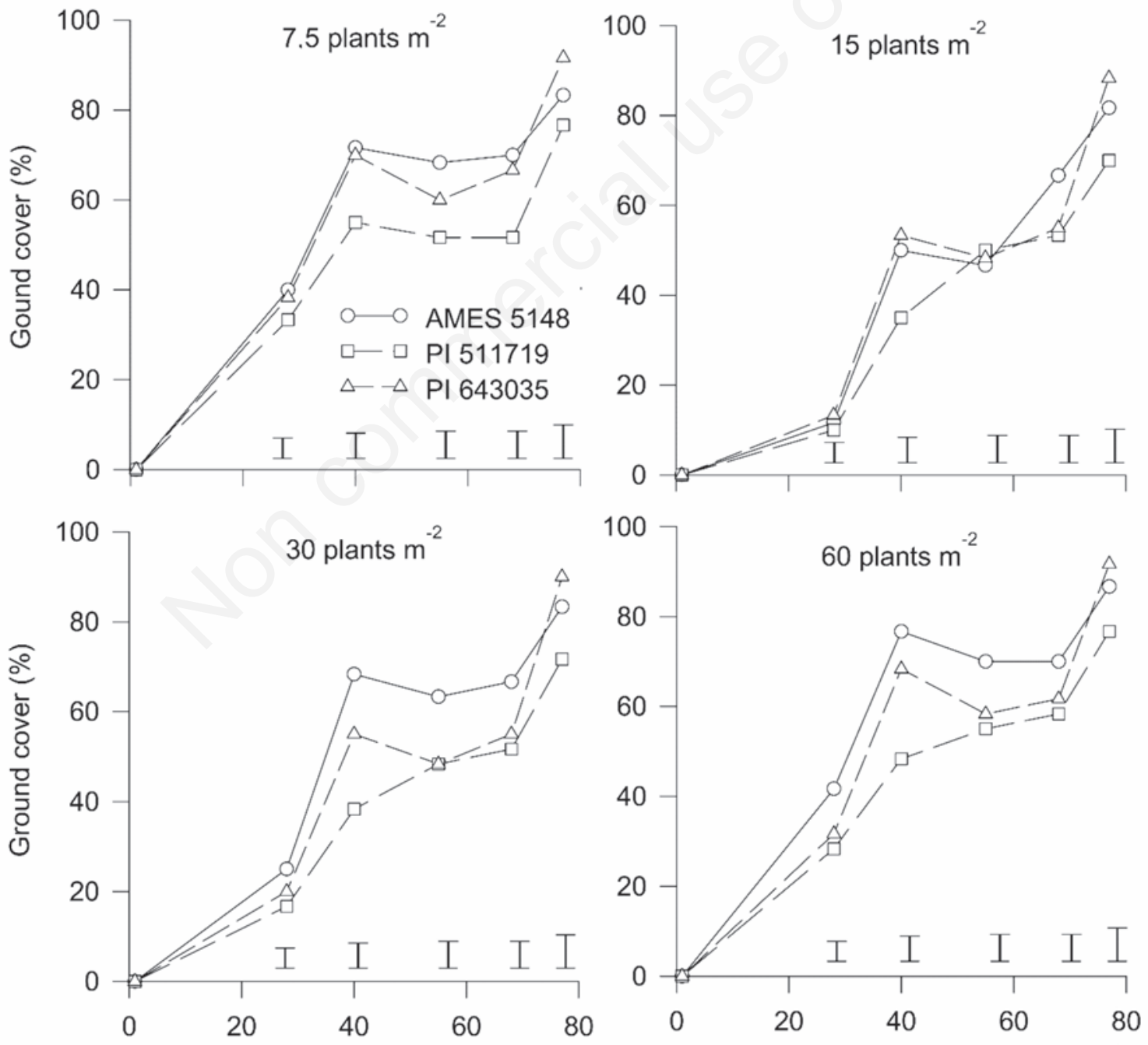

Days After Transplanting

Figure 4. Experiment 2. Trend of ground cover according to plant density and accessions. 
The Italian market for amaranth, as for other pseudo-cereals, is currently in the early stages, hence it is very difficult to draw conclusions about the profitability of the crop. In view of its many uses, amaranth could gain market ground where the demand for oil seeds is currently fulfilled exclusively from import. The quality of the base product (seed under the organic or biodynamic agriculture) and derivatives (e.g. oil) along with that of national origin may constitute a key entry into markets currently dominated by importation. In summary, given the possibility to cultivate this species in the Tuscan environment, a market should be created on the basis of compliance by industry (food and nonfood) to include amaranth products in their respective supply chains. Without this possibility, the utilisation and expansion of this pseudocereal crop will be very difficult.

\section{References}

Alba E, Polignano GB, Notarnicola L, 1997. Yield stability in a set of Amaranthus entries in Southern Italy. Ital. J. Agron. 1:65-71.

Apaza-Gutierrez V, Romero-Saravia A, Guillen-Portal FR, Baltensperger DD, 2002. Response of grain amaranth production to density and fertilization in Tarija, Bolivia. In: J. Janik and A. Whipkey (Eds.), Trends in new crops and new uses. ASHS Press, Alexandria, VA, USA, pp 107-109.

Ballabio C, Uberti F, Di Lorenzo C, Brandolini A, Penas E, Restani P, 2011. Biochemical and immunochemical characterization of different varieties of Amaranth (Amaranthus L. ssp.) as a safe ingredient for gluten-free products. J. Agric. Food Chem. 59:12969-74.

Berganza BE, Moran AW, Rodriguez MG, Coto NM, Santamaria M, Bressani R, 2003. Effect of variety and location on the total fat, fatty acids and squalene content of Amaranth. Plant Food Hum. Nutr. 58:1-6.

Casini P, Proietti C, 2002. Morphological characterisation and production of quinoa genotypes (Chenopodium quinoa Willd.) in the Mediterranean environment. Agr. Med. 132:15-6.

Downton WJS, 1973. Amaranthus edulis. A high lysine grain amaranth. World Crops 25:20.

Ercoli L, Masoni A, Massantini F, 1987. Influenza della fertilizzazione azotata sulla produzione di proteine da amaranto e chenopodio attraverso il frazionamento umido. Agric. Med. 117:131-9.

Garcia-Pereyra J, Valdés-Lozano CGS, Olivares-Saenz E, AlvaradoGómez 0, Alejandre-Iturbide G, Salazar-Sosa E, Medrano-Roldán H, 2009. Amaranthus (Amaranthus spp.) grain yield and forage quality after cultivation at various densities in Northeastern Mexico. Phyton (Buenos Aires) 78:53-60.

Gimplinger DM, Dobos G, Schonlechner R, Kaul HP, 2007. Yield and quality of grain amaranth (Amaranthus sp.) in Eastern Austria. Plant Soil Environ. 53:105-12.

Gonor KV, Pogozheva AV, Kulakova SN, Medvedev FA, Miroshnichenko LA, 2006. The influence of diet with including amaranth oil on lipid metabolism in patients with ischemic heart disease and hyperlipoproteidemia. Vopr. Pitan. 75:17-21.

Granados SD, Lòpez RGF, 1990. Chinampas: historia y etnobotanica de la "alegria" (Amaranthus hypochondriacus L.). In: El amaranto Amaranthus spp. Su cultivo e aprovechamiento. Colegio Postgraduate Montecillo, Montecillo, Mexico, pp 23-33.

Guillen-Portal FR, Baltensperger DD, Nelson LA, 1999. Plant population influence on yield and agronomic traits in 'Plainsman' grain amaranth. In: J. Janik and A. Whipkey (Eds.), Trends in new crops and new uses. ASHS Press, Alexandria, VA, USA, pp 190-193.

Haas PW, Kauffman CS, 1984. Grain amaranth: an overview of research and production methods. New Crops Dep., Rodale Res. Ctr., Rodale 
Press, Emmaus, PA, USA.

Hackam D, Myers R, 2003. Market opportunities for grain amaranth and buckwheat growers in Missouri. Report to the Federal-State Marketing Improvement Program, Washington, DC, USA.

Häuptli H, 1977. Agronomic potential and breeding strategy for grain amaranths. In: Proc. Amaranth Sem. ${ }^{\text {st }}$, Maxatawny, PA, 29 July 1977. Rodale Press, Emmaus, PA, USA, pp 71-81.

He HP, Cai Y, Sun M, Corke H, 2002. Extraction and purification of squalene from amaranth grain. J. Agric. Food Chem. 50:368-72.

He HP, Corke H, Cai JG, 2003. Supercritical carbon dioxide extraction of oil and squalene from Amaranthus grain. J. Agric. Food Chem. 51:7921-5.

Henderson TL, Johnson BL, Schneider AA, 2000. Row spacing, plant population, and cultivar effects on grain amaranth in the Northern Great Plains. Agron. J. 92:329-36.

Khandaker L, Ali MB, Oba S, 2008. Total polyphenol and antioxidant activity of red amaranth as affected by different sunlight level. J. Jpn. Soc. Horticult. Sci. 77:395-401.

Lovelli S, Pizza S, Caponio T, Gherbin P, Perniola M, 2005. Analisi di crescita e valutazione agronomica di alcune specie erbacee a basso tenore di glutine. In: Proc. 34th Congr. SIA, 20-22 September, Foggia, Italy, pp 298-299.

Massantini F, Masoni A, Ercoli L, 1987. Potenzialità agronomiche dell'amaranto e del chenopodio come specie adatte al frazionamento umido: prove biennali. Agric. Med. 117:31-41.

National Research Council, 1984. Amaranth. Modern prospects for an ancient crop. National Academy Press, Washington, DC, USA.

Peiretti EG, Gesumaria JJ, 1998. Influencia de la distancia entre lineas sobre el crecimiento y rendimiento de amaranto granifero (Amaranthus sp.). Investig. Agr. Prod. Prot. Veg. 13:139-51.
Petr J, Michalik I, Tlaskalova H, Capouchova I, Famera 0, Urmiska D, Tukova L, Knoblochova H, 2003. Extension of the spectra of plant products for the diet in celiac disease. Czech J. Food Sci. 21:59-70.

Pola Lòpez R, Spetter J, Lorenz K, 2007. El resurgimiento de un cultivo ancestral: amaranto. LEISA Rev. Agroetol. 23:19-22.

Putnam DH, 1990. Agronomic practices for grain amaranth. In: Proc. Natl. Amaranth Symp., 4th, Minneapolis, MN, 23-25 Aug. 1990. Minnesota Ext. Serv., Univ. of Minnesota, St. Paul, MN, USA, pp 151-162.

Rastogi A, Shukla S, 2013. Amaranth: a new millennium crop of nutraceutical values. Crit. Rev. Food Sci. Nutr. 53:109-25.

Rivelli AR, Gherbin P, De Maria S, Pizza S, 2008. Field evaluation of Amaranthus species for seed and biomass yields in Southern Italy. Ital. J. Agron. 3:225-9.

Saunders RM, Becker R, 1984. Amaranthus: A potential food and feed resource. In: Advances in cereal science and technology, volume VI. American Association of Cereal Chemists, Inc., St. Paul, MN, USA, pp 357-397.

Shin DH, Heo HJ, Lee YJ, Kim HK, 2004. Amaranth squalene reduces serum and liver lipid levels in rats fed cholesterol diet. Br. J. Biomed. Sci. 61:11-4.

Teutonico RA, Dietrich K, 1985. Amaranth: composition, properties, and application of a rediscovered food crop. Food Tech. 39:49-58.

Tucker JB, 1986. Amaranth: the once and future crop. BioSci. 36:9-13.

Weber LE, Applegate WW, Johnson DL, Nelson LA, Putnam DH, Lehman JW, 1989. Amaranth grain production guide. Rodale Press, Emmaus, PA, USA.

Yarnia M, Khorshidi Benam MB, Farajzadeh Memari Tabrizi E, 2010. Sowing date and density evaluation of amaranth (cv. Koniz) as a new crop. J. Food Agric. 8:445-8. 